\title{
Comment
}

\section{CONGRESSIONAL INVESTIGATIONS AND THE PRIVILEGES OF CONFIDENTIAL COMMUNICATIONS}

Two contemporary events have emphasized that the role of the congressional investigating committee, while undoubtedly firmly established in our political system, is still unclearly delineated as to scope and status. The problem of scope was illustrated in Watkins $v$. United States. ${ }^{1}$ The problem of status was exemplified in the recent controversy between the State Bar of California and the House Committee on Un-American Activities. ${ }^{2}$ The Watkins opinion disturbed the complacency that the scope of investigation was for all practical purposes unlimited by requiring, at least in a criminal prosecution for contempt for refusal to answer, that the question asked in committee be "pertinent" to clearly specified committee authorization and goals within a now at least potentially restricted "legislative purpose." On the other hand, the protest of the State Bar of Cabfornia against aspersive remarks made in a Los Angeles hearing by the counsel of a congressional subcommittee against counsel of a witness and the subsequent ejectment of attorneys who objected to the proceeding, ${ }^{4}$ as well as the rejoinder by one member of the subcommittee that the committee's work had been obstructed by the attorneys in question and the subcommittee attacked without a valid consideration of the facts, ${ }^{5}$ raises the issues of what degree of deference is due a committee from Congress and whether the attorney appearing before it should be identified with the characteristics of his client. These events serve to make it clear that the study and assessment of congressional committees must contmue.

The question of what rights should be afforded witnesses appearing before congressional committees is still unsettled. While this issue opens a wide field of dis-

1354 U.S. 178 (1957); accord, Sweezy v. New Hampshire, 354 U.S. 234 (1957).

2 See text at note 4 infra.

3 The federal statute in point makes it a misdemeanor to refuse to answer before a congressional committee "any question pertinent to the question under inquiry. ..." 11 STAT. 155 (1857), as amended, 2 U.S.C. $\$ 192$ (1952). In Watkins the Court reasoned that the witness, having the obligation of deciding whether a question posed to him was "pertinent to the question under inquiry," should receive a fair opportunity to determine whether the question posed was withm the authorization of the committee from its parent house and whether such authorization was valid. Such a fair opportunity was not given the witness and his rights were violated under the due process clause of the fifth amendinent: The authorization from the House of Representatives was so broad that it could include matters which Congress could not investigate under the first aniendment; even if the committee were acting within valid legislative goals, neither the authorization of the House to the committee, the authorization of the committee to the subconimittee, the opening renuarks of the chairman, nor the very material elicited at the hearing could fairly demonstrate to the witness exactly to what issue the questions posed to him were pertinent. Therefore, he could never decide whether or not he would act im violation of the criminal statute.

That a limitation to the scope of congressional inquiry might be formd by the courts is foreshadowed in Umited States v. Icardi, 140 F. Supp. 383 (D.D.C. 1956), 45 CALIF. L. Rev. 181 (1957). For a collection of pre-Watkins material that well could lead one to the conclusion that the scope of the congressional power of investigation was indeed unlimited, see NEWras \& SURREX, LEGISLATION 250-359 (1955).

4 The position of the State Bar is presented in an address by the President in which is incorporated the Statement of the Board of Governors. See Ball, Freedom of the Bar, 32 CALIF. S.B.J. 109, 115-19 (1957).

E See San Francisco Chronicle, June 19, 1957, p. 1, col.2. 
cussion, this Comment will be narrow in its approach, emphasizing only one sector of potential rights. Its thesis is that the privileges of confidential communications should be available to witnesses as a matter of statutory law. To provide a setting, this presentation is preceded by a survey of several of the rights already afforded witnesses by statute and by committee rule. No analysis is made of constitutional protections.

\section{PRESENT COMMITTEE RULES ${ }^{6}$}

While there is a continuous stream of material ${ }^{7}$ on the subject of the rights of witnesses before congressional committees, one should not lose sight of the fact that presently many matters have already been provided for by statute, a rule of either house, or a committee rule. ${ }^{8}$ The purpose of this section is to show, without any attempt at evaluation, how selected problems ${ }^{0}$ in this area are presently disposed of by statute or rule.

A large number of committees of the houses of Congress ${ }^{10}$ courteously replied

6 This Comment had as its forebearer a term project in the Legislation course of Professor Frank C. Newman, School of Law at Berkeley, University of California. The author wishes to acknowledge that a significant part of the material appearing in notes 7-39 infra was due to the work of Messrs. Gerald R. Knecht and René D. Zentner, co-authors of the term project. Needless to say, none of the gentlemen mentioned are responsible for the thesis of this Comment.

7 As an illustration, a list of congressional bills from 1948 until 1954 appears in Maslow, Fair Procedure in Congressional Investigations: A Proposed Code, 54 Colum. L. REv, 839, 842 n.15 (1954).

8 For a criticism of the situation in regard to the rights of witnesses even under the present structure, but without any specific analysis of the statute and rules already governing the matter, see Chase, Improving Congressional Investigations: A No-Progress Report, 30 TEMP. L.Q. 126 (1957). A succinct presentation arguing the need of reform from within an essentially sound system appears in Scott \& King, Rules for Congressional Committees: An Analysis of Honuse Resolution 447, 40 VA. L. REv. 249 (1954). A comparison of the rules now in force and the proposals for reform leads to the conclusions (1) that there are many important rules in existence, but they usually are not rules of any house but only of certain committees and (2) that very often a proposed rule for a house as a whole has particular coinunittee rules as forebearers.

- One series of problems not presented in the text centers around the "executive session." Certain possible hazards face the witness, viz., attendance at the session of non-committee personnel whose presence would be prejudicial to the witness, selected re-questioning in public session of matters isolated in executive session, and release of information discussed in executive session with deletions or emphasis that would be prejudicial to the witness. In regard to attendance, it is controlled hy the committee. E.g., Rule 6, House Committee on Government Operations, Legislative Calendar 6 (March 1, 1957); Rule IV-A(2), CoManITTEE ON UNAmirrican Activities, Rules of Procedure 2 (1953). And while the release of information gained in executive session requires committee approval under many rules, e.g., House of Representatives rule XI, para. 25(0) ; Rule 5, Senate Small Business Committee (Mimeo. dated as of Feb. 3, 1955), this would not hiterally curtail a seemingly spontaneous line of re-questioning, nor bar a committee from releasing only a partial transcript, although the release of unaterial by an individual committee member is apparently proscribed. Problems of this nature are discussed in Maslow, Fair Procedure in Congressional Investigations: A Proposed Code, 54 Colum. L. REv. 839, 866-67, 877-80 (1954), and Scott \& King, Rules for Congressional Committees: An Analysis of House Resolution 447, 40 VA. L. REv. 249, 260-66 (1954).

10 Replies were received from the following committees. Senate committees: Agriculture and Forestry; Appropriations; Armed Services; Banking and Currency; District of Columbia; Finance; Foreign Relations; Government Operations (including the Permanent Subcommittee on Investigations); Interior and Insular Affairs; Interstate and Foreign Commerce; Judiciary subcommittees: No. 1 (Immigration and Nationality), No. 2 (Claims), and Internal Security; Labor and Public Welfare; Post Office and Civil Service; Public Works; Rules and Administration subcommittee on Privileges and Elections; Small Business; Special Committee to Investigate Pohtical Activities, Lobbying, and Campaign Contributions. House commillees: 
to inquiry as to their present rules of procedure. The discussion below is based almost solely on these replies so that committees not mentioned but from which replies were not received might also fit into the discussion at various points. Furthermore, the absence of a particular rule in a certain committee, the absence of many coinmittees in regard to particular points, or the constant recurrence of certain committee names should be viewed with a realization that the presence or absence of a printed rule does not give a complete picture: Where there is no formal rule a custoin may still prevail; and the experience of some committees may have shown that a rule on a particular matter was never required, while the business of certain other committees have made such rules convenient or even necessary.

\section{Notice}

Published material from only two committees, ${ }^{11}$ both in the House, were found from which it could be concluded that potential witnesses are notified sufficiently in advance to prepare their testimony, but this may well be an excellent illustration of the point that often the absence of a printed rule may not be significant. As to the additional problem, whether in such notice the witness is sufficiently apprised as to the matters on which he should testify, no committee rule was found. ${ }^{12}$

The House Committee on Un-American Activities has an additional right of notice extending to persons not subpenaed or requested to appear. Its rules provide $^{13}$ that "where practicable, any person named in a public hearing ... as subversive, Fascist, Communist, or affiliated with one or more subversive-front organizations, ... shall, within a reasonable time thereafter, be notified by registered letter" of the accusation and its source. This notice is to afford the person so named an opportunity to appear as a witness.

\section{Prepared Statements}

While it is contemplated that witnesses will have prepared statements, ${ }^{14}$ the presentation of such statements is apparently kept under tight committee control. Generally, the committee may require in advance a written statement of proposed testimony and limit the prepared oral testimony to a brief summary of the argu-

Armed Services; Banking and Currency; District of Columbia; Education and Labor; Foreign Affairs; Government Operations; House Administration; Interior and Insular Affairs; Interstate and Foreign Commerce; Post Office and Civil Service; Public Works; Rules; Un-American Activities; Veterans' Affairs; Ways and Means. Joint committees: Atomic Energy; Defense Production; Internal Revenue Taxation.

11 Concurrttee on UN-AMrerican Activities, Rutes of Procedure 2 (1953) (rule III-B); Committee on Ways and Means, Mimeograph (entitled "Committee on Ways and Means") 1 (Undated).

12 For material on this problem see, e.g., Watkins v. United States, 354 U.S. 178 (1957); Axrerrcan Bar Ass'N, Report on Congresstonat Investigamions (1954) (APpendix 30-33).

13 Rule X, Connutree on UN-American Actrvities, Rules of Procedure 5-6 (1953). See Scott \& King, Rules for Congressional Committees: An Aralysis of House Resolution 447, 40 VA. L. Rev. 249, 268-71 (1954), for a proposal to embody into the rules of the House of Representatives a system of protection for nonwitnesses.

14 See, e.g., Rule XI, para. 25(f), of the House of Representatives: "Each committee shall, so far as practicable, require all witnesses appearing before it to file in advance written statements of their proposed testimony, and to limit their oral presentation to brief summaries of their argument. The staff of each committee shall prepare digests of such statements for the use of committee members." The memorandum received from the House Committee on Foreign Affairs states: "During liearings, witnesses usually present oral statements without interruption. ..." Committee on Foreign Affairs, Memorandum on Committee Procedure, para. 3 (Mimeo. March 1, 1955). 
ment. ${ }^{15}$ If the witness wishes to read a prepared statement or to insert it into the record, the rules of three Senate committees ${ }^{16}$ require that the statement must be presented within a certain time before testimony so that the committee may decide its disposition; the House of Representatives has a similar rule in regard to inserting a statement into the record. ${ }^{17}$

Persons not under subpena but who wish to appear to make statements are also considered in some of the committee rules. The rules of the House of Representatives state: ${ }^{18}$

If the committee determines that evidence or testimony at an investigative hearing may tend to defame, degrade, or incriminate any person, it shall - ... (2) afford such person an opportumity voluntarily to appear as a witness; . . .

The Committee on Un-American Activities complements this by providing ${ }^{10}$ that third parties to whom notice has been sent ${ }^{20}$ may request to appear and that these persons will have the rights of witnesses, which imclude the presentation of prepared statements for possible oral presentation or insertion into the record. ${ }^{21}$

Two Senate committees ${ }^{22}$ have published provisions similar to the House rule.

\section{Right to Counsel}

The right to counsel in a congressional hearing may have no constitutional foundation $^{23}$ and so probably must depend upon the discretion of Congress. While investigating committees have generally allowed counsel to accompany a witness, his role traditionally has been fairly· insignificant and usually limited to personal

15 In the Senate certain committees have this provision. Rule 6, Committee on Post Office and Civil Service, Legislative Calendar 7 (Feb. 11, 1957); Rule 8, Permanent Subcommittee on Investigations of the Committee on Government Operations, Legislative Calendar 5 (Dec. 17, 1956); Rule 12, Subcomartitee on Privileges and Elections of tare Commitiee on Rules and Admonistration, Rules of Procedure 5 (1956). The House committees operate under the rule quoted in note 14 supra.

16 Rule \%, Spectal Comontree to Investigate Poluticaz Activities, Lobiyang, and Casapaign Contributions, Rutes of Procedure 3 (1956); Rule 8, Permanent Subcommittee on Investigations of the Committee on Government Operations, Legislative Calendar 5 (Dec. 17, 1956); Rule 14, Subcomamtree on Privinges and Elections of the Comamirtee on Rules and Apministration, Rules of Procedure 5 (1956).

17 "In the discretion of the committee, witnesses may submit brief and pertinent sworn statements in writing for inclusion in the record. The committee is the sole judge of the pertinency of testimony and evidence adduced at its hearing." Rule XI, para. $25(\mathrm{p})$.

18 Rule XI, para. $25(\mathrm{~m})$.

10 Rule X-B, C, Comomtree on Un-Amertcan Activities, Rules of Procedure 5-6 (1953).

20 See text at note 13 supra.

21 See text at note 18 supra; Rule IX, Comamitree on UN-AMerucar Activities, RuLEs of Procedure 5 (1953).

22 Rule 12, Special Comomttex to Investroate Politicai Activities, Lobbying, ard Campatgn Contributrons, Rules of Procedure 4-5 (1956); Rule 19, Subcommttee on Privineges and Elections of the Commitree on Rules and Admtnistration 7 (1956).

23 See In re Groban, 352 U.S. 330 (1957), where appellants were denied a due process right to counsel in a state administrative proceeding to determine the cause of a fire even though the state official could arrest someone for arson on the information received. The Court draws a distinction between a prosecuting body, before which there is a right to counsel, and an investigatory body. 
advice to the witness. ${ }^{24}$ For example, Rule VII of the Committee on Un-American Activities states: 25

Counsel shall not be permitted to engage in oral argument with the Committee, but shall confine his activity to the area of legal advice to his client.

And the rules of three Senate committees ${ }^{26}$ emphasize that the privilege of attendance does not extend to authorizing the counsel

to coach the witness, answer for the witness, or put words in the witness' mouth.

The present rules in Congress continue this general approach. The House of Representatives' rule reads: ${ }^{27}$

Witnesses at investigative hearings may be accompanied by their own counsel for the purpose of advising thein concerning their constitutional rights.

It is clear from the floor debate that the wording "constitutional rights" was meant to be restrictive. ${ }^{28}$

The Senate has pubhished no uniform rule on the right to counsel. However, several committees have individually provided for counsel. Some rules simply state that the witness may have counsel to advise him of his legal rights. ${ }^{29}$ While this may be a broader right than that afforded in the House of Representatives, one might wonder whether the more complicated provisions of other Senate committees, ${ }^{30}$ specifying restrictions, do not really express the tenor of the situation:

Counsel retained by any witness and accompanying such witness shall be permitted to be present during the testimony of such witness at any public or executive liearing, and to advise such witness while he is testifying, of his legal rights; but this shall not be construed to excuse a witness from testifying in the event his counsel is ejected for contumacy or disorderly conduct; nor shall this rule be construed as authorizing counsel to coach the witness, answer for the witness, or put words in the witness' mouth. The failure of any witness to secure counsel shall not excuse such witness from attendance in response to subpena.

\section{Cross-Examination of Adverse Witnesses}

No present right to oral cross-examination has been found although in the past this privilege has been granted. ${ }^{31}$ However, a limited privilege of written cross-

24 For a general summary and history, see AMrericAN BAR Ass' $N$, REPort on Congressionar. Investigations (1954) (APPENDIX 34-66). Counsel for Henry Grunewald, after being warned by the House Committee on Ways and Means that its rules forbade interjections by counsel, was ejected from the liearing room for attempting to interpose objections to the questioning of his client. See H. R. Report No. 1748, 82d Cong., 2d Sess., 32-34 (1952). However, the committee earlier had waived this rule, for counsel was permitted to speak. See, e.g., id. at 13-17.

25 Conamtree on Un-Aamerican Activities, Rules of Procedure 3-4 (1953).

26 Rule 6, Special Comantitee to Invesimgate Politicat Activities, Lobbying, and Campaign Contributions, Rules of Procedure 2-3 (1956); Rule 7, Permanent Subcommittee on Investigations of the Committee on Government Operations, Legislative Calendar 5 (Dec. 17, 1956); Rule 16, Subconarimtee on Privileges and Erections of the Comantiree on Rules and Administration, Rules of Procedure 6 (1956). The texts of these rules are the same.

27 Rule XI, para. 25(k).

28 See 101 Cong. REc. 3570, 3572, 3573 (1955). The Committee on Un-American Activities may grant a broader right than the House rule, for it allows counsel to advise the witness as to his legal rights. The right to engage in oral argunent with the committee is denied, however. Rule VII-B, Comantree on Un-Amarican Actrvities, Rules of Procedure 3-4 (1953).

20 Rule 9, Committee on Armed Services, Legislative Calendar 4 (Dec. 15, 1956); Rule 6, Committee on Banking and Currency (Undated Mimeo.); Rule 6, Small Business Committee (Mimeo. dated as of Feb. 3, 1955) ; accord, Rule 5, Joint Committee on Defense Production (Undated Mimeo.).

30 Rules cited in note 26 supra.

31 Ajterican Bar Ass'n, Report on Congresstonal Investigations (1954) (Appendix 67-73). 
examination is permitted in three Senate committees. ${ }^{32}$ The rules of these committees state that while interrogation of witnesses at hearings shall be conducted only by nnembers or staff personnel, "any person [witness or not] who is the subject of an investigation" may submit written questions for cross-examination. The consent of a majority of the committee present and voting is necessary for the questions to be used, and they are asked by some member of the body. In contrast, the Committee on Un-American Activities does not state even this limited privilege in its printed rules. On the contrary, it may specifically deny it, for its manual of rules states that in order to carry out properly the function of the committee, "the rules of evidence, includimg cross-examination, are not applicable."33

\title{
Television Broadcasting
}

The particular use of television lights and cameras may so upset decorum or disturb the witness as to invalidate the hearing itself insofar as subsequent criminal proceedings are concerned. ${ }^{34}$ Consequently, not only has there been a good deal of discussion of this problem, ${ }^{35}$ but certain committees have formulated rules on the inatter.

Two Senate committees ${ }^{36}$ merely give their respective chairmen the authority to grant or deny the privilege of televising public sessions. Three other Senate committees $^{37}$ formalize the rule in terms of a request by the witness:

\begin{abstract}
A witness may request, on grounds of distraction, harassment, or physical discomfort, that during his testimony, television, motion picture, and other cameras and lights shall not be directed at him, such request to be ruled on by the subcommittee members present and voting.
\end{abstract}

In the House of Representatives only the Committee on Un-American Activities was found to have a published rule on the matter. This rule not only instructs the broadcasters on how they may employ their cameras, but apparently also makes mandatory a witness' request that the cameras not photograph him during his tes-

32 Rule 11, Spectad Comantree to Investigate Polrticat Activiturs, Lobbyang, and Campatge Contributions, Rules of Proctedure 4 (1953); Rule 12, Permanent Subcommittce on Investigations of the Committee on Government Operations, Legislative Calendar 5-6 (Dec. 17, 1956); Rule 18, Subcommittee on Privineges and Elections of the Committee on Rutes and Administration, RuIes of Procedure 7 (1956).

33 Comamtree on Un-American Activities, Rules of Procedure 7 n.4 (1953).

34 Compare United States v. Kleinman, 107 F. Supp. 407 (D.D.C. 1952) (use of television and newsreel cameras created an inproper atınosphere so as to excuse witness from contempt), with United States v. Moran, 194 F.2d 623 (2d Cir. 1952) (presence of television cameras and microphones did not render the hearing lacking in decorum).

35 See, e.g., Maslow, Fair Procedure in Congressional Investigations: A Proposed Code, 54 Corva. L. Rev. 839, 876, 889 (1954) ; Church \& Wasilewski, Televising Legislative Hearings, 14 FED. B.J. 59 (1954); Broadcasting and Televising of Congressional Comtmittee Hearings, 14 FED. COMaM. B.J. 132 1955); Snee, Televising Congressional Hearings, 42 Gro. L.J. 1 (1953).

36 Rule (2), Committee on the District of Columbia (Undated Mimco.) ; Rule 3, Committee on Intcrstate and Foreign Commerce, Legislative Calendar 2 (Fcb. 26, 1957) (concurrence of ranking minority member also required to allow televising).

37 Rule 8, Special Committee to Investicate Political Activities, Lobbinng, and Camapatgr Contributions, Rules of Procedure 3 (1956); Rule 9, Permanent Subcommittce on Investigations of the Committee on Government Operations, Legislative Calendar 5 (Dec. 17, 1956); Rule 23, Subcomentrtee on Privineges and Elections of the Comaittee on Rules and Administration, Rules of Procedure 8 (1956). The texts of the thrce rules are the same. 
timony..$^{38}$ However, recent events indicate that no television broadcasting at all is in accordance with House rules. ${ }^{30}$

\section{PRIVILEGES OF CONFIDENTIAL COMMUNICATIONS ${ }^{40}$}

\section{The Present Position of the Privileges in Congressional Hearings}

The legal status of the privileges of confidential communications before congressional committees in absence of special legislation has never been settled by the courts. ${ }^{41}$ Nor does any statute embody them for this purpose. The rules of only one committee, the Committee on Un-American Activities, have been found recognizing them to any extent. ${ }^{42}$ Historically, privileges of confidential communications have been asserted from time to time; ${ }^{43}$ in at least two instances the appro-

38 " $\mathrm{B}$-Upon the request of a witness that no telecast be made of him during the course of his testimony, the Chairman shall direct that television cameras refrain from photographing the witness during the taking of his testimony." Rule XIII, CoMasITteE oN UN-AMarICAN ActTvities, Rules of Procedure 7-8 (1953).

89 See San Francisco Chronicle, June 28, 1957, p. 1,'col. 2.

40 Not treated here as ineluded within the privileges of confidential communications is the subject of the various governmental privileges, e.g., as asserted in court or between the executive and the legislature. See, generally, Jencks v. United States, 353 U.S. 657 (1957) ; McCoRsack, Evidence c. 15 (1954); NewMaN \& Surrey, Legislation 534-63 (1955); 8 WigMore, EvIDENCE c. LXXXV (3d ed. 1940); Hearings Before a Subcommittee of the House Committee on Govertment Operations Regarding Availability of Information from Federal Departments and Agencies, 84th Cong., 2d Sess. (1956).

41 A few older decisions indicate that the privileges of confidential communications cannot be forced on the legislature. Stewart v. Blaine, 1 MacArthur 453 (D.C. 1874) (House of Representatives hearing); Ex parte Parker, 74 S.C. 466, 55 S.E. 122 (1906) (dictum); In re Falvey, 7 Wis. (7 Vilas \& Bryant) *630 (1858). Stewart depends on Anderson v. Dunn, 19 U.S. (6 Wheat.) 204 (1821), the breadth of which was disapproved in Kilbourn v. Thompson, 103 U.S. 168 (1880); the attorney-chent privilege was argued, but the court did not expressly discuss it. Parker assumes there was no violation of privilege, but its decision is based on the broad theory that privileges are merely rules of evidence subject to legislative control. Falvey states that the importance of investigations to protect the operation of government makes it "unwise" to restrict legislative committees to rules of evidence.

But two decisions muddy the waters. In United States v. Keeney, 111 F. Supp. 233 (D.D.C. 1953), rev'd on other grounds, 218 F.2d 843 (D.C. Cir. 1954), the court denied the assertion before a congressional committee of a confidential privilege of United Nations employees. The court, instead of stating that no privileges exist before such committees, demed the asserted privilege on the grounds that it in particular was not recognized under United States law. The language of the court intimates that it might have given effect to a recognized privilege. In Sullivan v. Hill, 73 W. Va. 49, 55-56, 79 S.E. 670, 672 (1913), the court in dictum states that had the fact asserted raised an attorney-client privilege, the privilege might have been honored before the state legislative committee in point.

Quaere: If the privileges can be barred in congressional hearings, can a committee do so in absence of legislation or other direction to that effect?

Cf. SEC v. Harrison, 80 F. Supp. 226, 230 (D.D.C. 1948), where the court states the attorney-client privilege is available in an administrative hearing in order to protect the attor. ney-client relationship. Accord, In re Albert Limdley Lee Memorial Hospital, 209 F.2d 122, 124 (2d Cir. 1953) (dictum); McMann v. SEC, 87 F.2d 377, 378 (2d Cir. 1937) (dictum). While the facts of the Harrison case refer to an administrative hearing, the reason stated for upholding the privilege apphes equally to legislative hearings.

42 Rule XII, Commitee on Un-Ammerican Activities, Rules of Procedure 7 (1953): "Relationship of Husband and Wife: The confidential relationship between husband and wife shall be respected, and for reasons of public policy, one spouse shall not be questioned concerning the activities of the other, except when a majority of the Committee or Subcommittee shall determime otherwise."

${ }^{43}$ E.g., Hearings Before the Internal Security Subcomsnittee of the Senate Judiciary Committee on Subversive Influence in the Educational Process, 82d Cong., 2d Sess. 61-62 (1952) (spousal privilege asserted and accepted) ; Hearings Before the House Committee on Un-Ameri- 
priate house of Congress has reacted unfavorably, but neither instance can be considered a denial of the privileges in general. ${ }^{44}$ The words of Senator William E. Jenner, Chairman of the Senate Committee on Rules and Administration while it was contemplating legislation embodying certain privileges, probably best exemplify the attitude which up to now has prevailed: 45

With few exceptions, it has been committee practice to observe the tostimonial privileges of witnesses with respect to communications between clergyman and parishioner, doctor and patient, lawyer and client, and husband and wife. Controversy does not appear to lave arisen in this connection. While the policy behind the protection of confidential communications may be applicable to legislative investigations as well as to court proceedings, no rule appears to be necessary at this time.40

It is respectfully submitted, however, that the potentiality of controversy should require a determination now, not in the heat of some particular investigation. Furthermore, voluntary committee recognition of the privileges may not protect them at the very moments of stress when protection is needed. Legislation clearly establishing the privileges of confidential communication as a part of the body of rights of witnesses is now necessary.

It is submitted that one important reason for the lack of favorable legislation is the dearth of material explaining why the privileges should be available in legislative hearings in particular. To extol the privileges without identifying their place in the legislative picture is not enough. Examples of this incomplete approach are the proposals that the privileges allowed in federal criminal courts should apply in congressional hearings. ${ }^{47}$ Not only is this too uncertain a standard to apply, ${ }_{18}$ but this places on a political organization tests designed to apply to a judicial body.

can Activities Regarding Communist Espionage in the United States Government, 80th Cong., 2d Sess., 1216, 1308-09, 1342-46, 1438 (1948) (attorney-client privilege asserted and in at least one instance, at 1438, apparently accepted) ; Hearings Before the House Un-American Activitive Committee on Communism in the Motion Picture Industry, 80th Cong., 1st Sess. 367-69 (1947) (attorney-client privilege asserted).

44 Covg. Grose, 42d Cong., 3d Sess. 952-56 (1873) (attorney-chent privilege denied); 78 CoNG. Rec. 1851-53, 2397-2410, 2494-98, 2710-11 (1934) (attorney-client privilege denied). In both cases the recalcitrant witness was brought before the bar of the respective liouse. But in the 1873 instance the House of Representatives assumed the privilege was available and only debated the issue of whether it had been properly asserted. And in the 1934 instance the Senate debated behind closed doors.

45 S. REP. No. 2, 84th Cong., 1st Sess. 27-28 (1955) (footnotes omitted).

40 This statement is contained in a committee report resulting from a hearing on several bills relating to committee procedure. See note 44 supra. The two bills receiving most attention were S. Res. 253 and S. Res. 256, 83d Cong., 2d Sess. (1954). The latter contained a section protecting certain privileges of confidential commumication, $\$ 3(d)$ of S. Res. 256, while the former did not. Senator Paul Douglas inserted a statement into the record arguing the merits of S. Res. 256 over S. Res. 253. Reference to $\S 3$ (d) was conspicuous by its absence. Hearings Before the Subcommittee on Rules of the Senate Committee on Rules and Administration Regarding Rules of Procedure for Senate Investigating Committees, 83d Cong., 2d Soss., pt. 8, at 505 (1954).

47 E.g., Maslow, Fair Procedure in Congressional Investigations: A Proposed Code, 54 CoLUM. L. REv. 839, 889 (1954) (\$10(b) of Model Code).

48 See Louisell, Confidentiality, Conformity and Confusion: Privileges in Federal Court Today, 31 Tur. L. Rev. 101, 122 (1956); cf. 44 Carre. L. REv. 949 (1956). Mr. Ernest Angell, Chairman of the Board of Directors of the American Civil Liberties Union, in discussing $\S 3$ (d) of S. Res. 256, 83d Cong., $2 d$ Sess. (see note 46 supra), stated that the protection of the privileges of confidential communications should be broad enough to include all the privileges recognized in federal courts and then added: "I want to say, in passing, I do not know what those other [i.e., other than those already expressed in $\$ 3(\mathrm{~d})$ ] categories nay be. . . " Hearings Before the Subcommittee on Rules of the Senate Committee on Rules and Administration Regarding Rules of Procedare for Senate Investigating Committees, $83 \mathrm{~d}$ Cong., 2d Sess., pt. 4, at 196 (1954). 


\section{Privileges of Confidential Communications Should Be Available} in Congressional Hearings

The determination of whether privileges of confidential communications should be available in congressional hearings-and if so, which privileges-depends on a balancing of two problems, each of which must be resolved in itself: (1) What is the nature of these privileges? (2) What is the nature of a legislative hearing?

As for the first, the answer really lies in establishing a position between one of two opposed value judgments. The orthodox and probably generally accepted position, urged by Professor Wigmore, ${ }^{49}$ is that each person owes a duty to certain duly constituted bodies of society to give complete disclosure. Privileged commumications, which are hittle more than handicaps to society's quest for the truth, are a matter of grace and should be allowed only where-assuming that there is a confidential relationship and that the communication was in confidence-society wishes to "sedulously foster" the relationship and the mjury to the party will be greater than benefit to society in gaining the information.

The other position, of which Professor Louisell can undoubtedly be considered an exponent, ${ }^{50}$ emphasizes that Western society recognizes an individual right to privacy, that such a right includes confidences between persons, and that the privileges serve to protect this right. When a confidence runs athwart a fact-finding body and a privilege is recognized, this is not an attack on the quest for truth but a further protection of individual integrity.

As for legislative hearings, enough has been said elsewhere ${ }^{51}$ so as not to require further elucidation. The issue here is whether the information to be elicited by exposing the contents of a confidential communication must so necessarily be received that the possibility of personal exposure cannot be a deterring factor. On the one hand, the legislative hearing is not a contest to determine the legal position of an individual. Regardless of what a particular hearing may become, the investigation is a means Congress uses to gather material upon which future legislation may be based. ${ }^{\mathrm{E} 2}$ If a privilege of confidential communication is recognized, it has

49 WIGMORE, EvIDENCE $\$ 2192$ (duty to testify), 2195 (legislature), 2285 (general standards for privileges), 2291 (attorney), 2332 (spouse), 2380 (doctor), 2396 (clergyman) (3d ed. 1940) ; accord, De Parcq, The Uniform Rules of Evidence: A Plaintiff's View, 40 MinN. L. Rev. 301, 322-27 (1956); Chafee, Privileged Communications: Is Justice Served or Obstructed by Closing the Doctor's Mouth on the Witress Stand?, 52 Yare L.J. 607 (1943); McCormick, Law and the Future: Evidence, 51 Nw. U.L. Rsv. 218, 220-21 (1956); id., Some Highlights of the Uniform Evidence Rules, 33 TExas L. Rev. 559, 569-71 (1955); Morgan, Suggested Remedy for Obstructions to Expert Testimony by Rules of Evidence, 10 U. CEI. L. REV. 285, 286-92 (1943).

co Louisell, Confidentiality, Conformity and Confusion: Privileges in Federal Court Today, 31 Tor. L. Rev. 101 (1956); accord,. Manley, Patient, Penitent, Client and Spouse in New York, 21 N.Y.S.B.A. BurL. 288 (1949); see Radin, The Privilege of Confidential Commantication Between Lawyer and Client, 16 CAIT. L. REv. 487 (1928) ; cf. Connery, The Right to Silence, 39 Marq. L. REv. 180 (1956); Hammelmann, Professional Privilege: A Comparative Study, 28 CAN. B. Rev. 750 (1950).

GI Interesting discussions concerning the role of congressional investigating committees by persons having experience in them appears in Fulbright, Congressional Investigations: Significance for the Legislative Process, 18 U. CHI. L. Rev. 440 (1951); Meader, Congressional Investigations: Importance of the Fact-Finding Process, id. at 449; and Voorhis, Congressional Investigations: Inner Workings, id. at 455 .

52 See, e.g., Hearings Before the Subcommittee on Rules of the Senate Committee on Rules and Administration Regarding Rules of Procedure for Senate Investigating Committees, 83d Cong., 2d Sess., pt. 2, at 67 (1954) (testimony of Senator Gillette) ; COMMIITEE ON UN-AXIERICaN Activities, Rules of Procedure 7 n.4 (1953). 
hindered a process concerned with far broader matters than the determination of individual controversy. On the other hand, in fact hearings have often become adversary in nature and accusatory in fashion. ${ }^{53}$ The very movement for procedural reform of congressional investigations is motivated by the desire to protect witnesses who have thus become personally involved. There is no "trial" because a formal judicial body is lacking and civil and penal sanctions are not rendered. But very often the imvestigators will marshal facts or direct questions to the end that a witness is adversely spotlighted, ${ }^{54}$ and sanctions equally effective can result..55 The more a witness is thus made an adversary of the investigators, the more the imposition of safeguards becomes appropriate.

The doctrine of confidence-for-its-own-sake is to be rejected, but the opposite position of excluding any rights in congressional hearings is also to be forsaken. To a large degree our society recognizes the value of protecting individual confidences; where certain confidences are found worthy of protection in some circumstances, they should be given deep consideration in other circumstances also. While the forum wherein the privilege is to be asserted must be viewed in regard to its own peculiarities, basically the crucial moment at which to test the confidence is the time the communication is made, not when it is requested to be disclosed.60 The congressional hearing should not be immune from these considerations.

A recognition of at least some of the privileges will not hamper the legislative process. The argnment against the privileges in court is that they prevent the exposition of important facts. ${ }^{57}$ The privileges are not such a bar in a legislative committee. First, the legislature is not bound by an intrieate scheme of evidentiary rules. If the fact covered by the privilege is essential to the inquiry, the alert and competent investigator, aided by the committee staff, should be able to find this fact without exposing at the same time the subjective communication of the confidence. Secondly, the kinds of facts a committee requires usually will not be like those so essential to a court. It is no tautology to urge that the congressional committee is interested in "legislative facts," that is, in facts designed to cure a general situation, not necessarily only facts required to solve a certain problem about par-

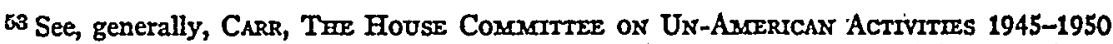
(1952); NewaAaN \& SURREX, LeGisLatToN c. 5 (1955); Garrison, Congressional Investigations: Are They a Threat to Civil Liberties?, 40 A.B.A.J. 125 (1954); Galloway, Congressional Investigations: Proposed Reforms, 18 U. CHI. L. REv. 478 (1951).

04 See note 53 supra.

$65 C f$. the dissent of Justice Douglas in Ullmann v. United States, 350 U.S. 422,440 (1956).

VB The more communication is susceptible of disclosure, the less it is protected. Consequently, the relationship imposing the confidence must be viewed in its entire position in society, and the point of focus should be on the confidence itself. If the disclosure of the conversation resulting from the confidence can be forced in some circumstances, the net result is that in reality the confidence has very defective protection even though disclosure cannot be forced in other circumstances.

Professor Falknor takes a definite stand in accordance with this philosophy when he writes, "The [common law] privileges rest on the notion of the necessity of according to the client, spouse, or other coninumicant, complete freedom of apprehension from subsequent counpulsory disclosure, and this is not acconplished unless disclosure in any sort of proceeding is forbidden," and in regard to statutory privileges, "And I think that such a statute [referring to a statute of the kind proposed in this Comment] should likewise respect the statutory privileges ... where the communication was inade in a jurisdiction recognizing the privilege in question, regardless of where the congressional hearing is held." Letter fron Judson F. Falknor to Donald M. Cahen, March 13, 1957.

57 See note 49 supra. 
ticular parties. What has a committee lost if despite other techniques facts concerning one man are barred? Other situations are still available for study. ${ }^{58}$

The proposed statute to follow has been designed in light of these policy problems and to present to the reader a point of reference froun which further discussion may engender. At this juncture at least, only certain privileges having a settled degree of recognition in the courts have been chosen-attorney-client, spousal ("familial" under the statute), doctor-patient, and religious. ${ }^{59}$ This selection is not based on court recognition, however. The primary reason for selection emphasizes the reliance of the communicants themselves: The relationships selected are themselves worthy of protection, and, the privileges being widely recognized, there is a reliance which induces the very confidential relationship a more obscure privilege would not. A second reason is one of convenience: Court recognition, either from a common law or statutory basis, affords a body of reference with which to administer the use of the privileges selected.

On the other hand, given the few privileges selected, their scope has been extended to encourage greater hiberality of protection by not including many of the developed exceptions to the privileges and by expressing certain extensions from the normal rule. This position is based on the philosophy that once the particular confidential relationship is found worthy of protection in congressional hearings, wider protection than the courts afford is worthwhile because of the political peculiarities of legislative hearings, especially the other means a committee has to gather facts and the usually overwhelming respect and authority commanded by a committee vis-a-vis the individual witness, the committee being a potential judge and prosecutor in one.

\section{Proposed Federal Statute Applicable to Congressional Committees}

Sec. 1. (a) An attorney shall not testify without the consent of his client as to any confidential communication made between them in the course of the attorneyclient relationship. A person shall have the right to refuse to testify as to the communication if he was the client. However, if the client gives his consent that the contents of the communication be disclosed, the attorney shall not refuse to testify on the grounds of this privilege.

(b) An employee or agent of the attorney who has knowledge of the communication by reason of the professional activity of the attorney is subject to the same rules concerning disclosure as the attorney.

(c) Any individual who heard the communication without the consent of the client shall not testify as to the communication without the consent of the client.

$68 \mathrm{It}$ is suggested that the recent investigation into the mismanagement of labor unions offers an illustration. Despite a multitude of refusals to testify based on the privilege against self-incrimination, can it be denied that the committee is nonetheless receiving ample material upon which to base future legislation and that the public is being informed on the problem? Cf., e.g., N.Y.Times, March 27, 1957, p.1, col.8.

60 Two important possibilities not included in the statute are the privilege of newspaperInen to withhold sources of information and the accountant-client privilege. The newsman privilege was not included because (in contrast to all the privileges selected except, to a degree only, the religious privilege) it is under the control and for the benefit of the professional, not the non-professional. As a result, considerations for the protection of this privilege are different from those in regard to the privileges selected. Compare Desmond, The Newsmen's Privilege Bill, 13:2 Arbany L. REv. 1 (1949) (privilege defended), with Gallup, Further Consideration of a Privilege for Newsmen, 14 ALBANY L. Rev. 16 (1950) (privilege attacked).

The accountant-client privilege was not included because of a doubt as to its general acceptability. For example, Wignıore lists only eight states having such a privilege, all by statute, the last having been passed in 1946. 8 WIGMORE, EvidENCE $\$ 2286$ (Supp. 1955). 
Comment. In the attorney-client relationship discretion is a watchword. The attorney is sought by the client as a legal "alter ego," necessary to many every-day activities, necessary to a witness for the very preparation of committee testimony. ${ }^{60} \mathrm{It}$ is considered unfair, as well as a hindrance to the very important relationship between attorney and client, ${ }^{61}$ to force a legal counselor to testify against his client. ${ }^{62}$

The final sentence of subsection (a) makes it clear that the client is the "owner" of the privilege, not the attorney, ${ }^{63}$ so that it is certain that the client may require the attorney to speak. ${ }^{64}$ The statute in subsection (c) eliminates the "eavesdropper principle," which allows an individual who overheard the communication to testify to it even without the consent of the owner of the privilege. The intent and reliance of the owner has remained the same despite the eavesdropping, and he should be protected. The principle of subsection (c) has also been used in the other privileges in this statute.

Sec.2. (a) Any individual who is a party to a confidential communication with a member of his family has the right to refuse to testify as to the communication and to prevent any family member who was a party to or heard the communication to testify thereto. Furthermore, any individual who heard the communication without the consent of all the family members who were parties to the communication shall not testify as to the communication without the consent of all the parties to it.

(b) Individuals are members of the same family within the meaning of this statute if they stand in any of the following relationships:

(1) spouses,

(2) parent or step-parent and child, provided that if the relationship

be only that of step-parent and child, the two must live in the same household (For the purposes of this statute, an adopted child shall be treated as a natural child.), or

(3) siblings by a common natural parent, provided that if the siblings

do not have both the same natural parents, the siblings must live in the same household.

Comment. This is a family privilege, but in reality it is beheved that this is the present spousal privilege recognized in its proper scope. The desire to protect the marital status through the recognition of a confidential relationship is, it is sub-

60 See, e.g., Hearings Before the House Committee on Un-American Activities Regarding Communist Espionage in the United States Government, 80th Cong., 2d Sess. 1308-09 (1948), and Hearings Before the House Committee on Un-American Activities on Communism in the Motion Pictutre Industry, 80th Cong., 1st Sess. 367-69 (1947), for examples of attorneys asserting the privilege in regard to advice allegedly given clients in preparation for their appearances before the committee.

61 See SEC v. Harrison, 80 F. Supp. 226, 230 (D.D.C. 1948).

62 Even Professor Wigmore admits that such a position is quite tenable. 8 Wigmore, EviDENCE 557 (3d ed. 1940). Contra, Morgan, Suggested Remedy for Obstructions to Expert Testimony by Rules of Evidence, 10 U. CHI. L. REv. 285, 288-90 (1943).

63 See McCormick, Evidence § 96 (1954); 8 Wigmore, Evidence $\$ 2321$ (3d ed. 1940 ). At one time the privilege was the attorney's, not the client's. Id. $\$ 2290$.

64 But of. $\$ 4$ of the proposed statute, text at note 71 infra, wherein the clergyman may even prevent the other party to the communication from disclosing its contents.

658 WIGMORE, EvideNCE § 2326 (3d ed. 1940) (attorney-chent privilege); McCormick, Evidence $\$ 86$ (1954) (spousal privilege). But see CaL. Pen. Code \$ 653(i) (1957) (a felony to eavesdrop on or record, by means of an electronic or other device, a conversation between a person in custody or on the property of a public agency and his attorney, rehgious advisor, or licensed plyysician); UNIFORM RUIES OF EvIDENCE rule 26(1)(c) (eliminates "eavesdropping principle" fron attorney-client privilege). 
mitted, based on a more fundamental desire to protect the family; therefore, this confidence should be protected in the same way even though, admittedly, the degrees of confidence between family members differ.

Subsection (b) is an attempt to find a reasonably delineated area of relationship in which to apply this broader privilege. The subsection limits the privilege to natural and adopted relationships of a particular degree, or their equivalent as restricted by the express test of "same household." Actually, the test of "same household" permeates the entire privilege. Natural and adopted relationships of the degree protected, while protected under the statute whether the individuals live together or not, were selected under the belief that the household commonly develops around these individuals; and the non-natural relationships were then made to conform to the "same household" philosophy. Subsection (b) (3) illustrates. The opening phrase combimes the natural and adopted relationships (because under subsection (b) (2) the adopted child is treated as a natural child), but the rest of subsection (b) (3), which refers only to "step-siblings," has the "same household" test.

The orthodox rule in the spousal privilege is that it may be asserted only by the communicating spouse, not the communicatee. ${ }^{66}$ However, the exceptions offered by the proponents of this rule, ${ }^{67}$ as well as the behef that the spousal privilege, in contrast to a professional privilege, in reality protects the confidences of both persons, has led to the rejection of this distinction in the proposed statute. ${ }^{68}$

Sec. 3. (a) A doctor ${ }^{69}$ shall not testify without the consent of his patient as to any confidential communication made between them in the course of treatment or during an examination for the purpose of treatment. An individual has the right to refuse to testify as to the communication if he was the patient. However, the doctor-patient privilege shall extend only to matters which enable the doctor to make a diagnosis or to prescribe or render treatment. If the patient gives his consent that the contents of the communication be disclosed, the doctor shall not refuse to testify on the grounds of this privilege.

(b) An employee or agent of the doctor who has knowledge of the communication by reason of the professional activity of the doctor is subject to the same rules of disclosure as the doctor.

(c) Any individual who heard the communication without the consent of the patient shall not testify as to the communication without the consent of the patient.

Comment. The doctor-patient privilege has been criticized as being unsound because the doctor-patient relationship needs no protection: One will seek medical advice unmindful of extrinsic consequences. ${ }^{70}$ If so, because of this very fact the privilege is accepted. It is, again, unfair to have a party seek aid under what are really involuntary circumstances with no real chance to refuse and then to have disclosures turned against him.

Sec. 4. Any individual who engages in a confidential communication with a clergyman in the course of the latter's capacity as a religious advisor shall have the right to refuse to testify as to the communication. The clergyman also has a

B6 \& Wigmore, Evidence \& 2340 (3d ed. 1940); McCormick, Evidence \& 87 (1954).

07 See, e.g., ibid.

68 See Louisell \& Crippin, Evidentiary Privileges, 40 MTNN. L. REv. 413, 415 (1956).

${ }^{69}$ See $\$ 8(7)$ of the proposed statute, text at note 77 infra, for the definition of "doctor," which includes the lay psychologist under certain circumstances.

70 E.g., Morgan, Suggested Remedy for Obstructions to Expert Testimony by Rules of Evidence, 10 U. CHI. L. REv. 285, 290-92 (1943). 
right to refise to testify. No individual shall testify as to the communication without the consent of all parties to it.

Comment. The religious privilege is included as a recognition in our society of the highly personal nature of religious feeling and the general tolerance thereof. It should be noted that in this privilege the professional person also las the right to prevent disclosure of the communication, even disclosure by the other party.

The privilege as stated is broader literally than orthodox expressions of it, for these would protect only those individuals of the clergyman's faith and only then in communications made obligatory by the religion. ${ }^{71}$ This restrictive interpretation is not agreed with here. The statute is to protect the religious confidences of all persons, even when consulting a clergyman of another faith. ${ }^{72}$ Such confidences slould be protected, if not encouraged. There is no grave danger of abuse: Not only must the communication be confidential, but the matter must be one about which an individual would go to a clergyman because of the latter's religious status. For example, discussions by a contractor with his minister about the cost of building materials for the church would not be privileged in a congressional investigation of housing profiteering; but conversations even with a minister of another faith about the proper way to make restitution because of the contractor's use of improper building materials would be privileged in the same investigation. In the first situation the minister is nothing more than another customer of the contractor, while in the second the minister lias been approached because of the advice lie can give on what is essentially an emotional matter.

Sec. 5. (a) "Consent" to the disclosure of the contents of a privileged communication can be made only to the hearing group in writing or orally while the person able to consent is a witness before the hearing group.

(b) To be effective consent must be received during the same hearing at which the privileged information is requested.

(c) A privilege of confidential communication shall never be considered waived unless during the same hearing at which the waiver is asserted a witness has disclosed without violating this statute all or soine of the contents of the privileged communication. The waiver shall apply only to the contents of the conimunicationi disclosed but not to the contents of other privileged communications in which the same matters were communicated.

Comment. The strictness of this section is designed not only to protect the privileges further but also to minimize later questions of fact as to whether in a given instance consent or waiver had occurred. ${ }^{73}$ It is believed that the effect of such strictness on the investigator's ability to obtain facts is mitigated by the other techniques of fact-finding. ${ }^{74}$

Sec. 6. No claimed privilege of confidential communication shall be denied on the ground that the communication took place in furtherance of a future crime, tort, or other wrong.

Comment. No doctrine limiting the scope of the privileges is accepted in this statute unless expressly mentioned. However, it is felt that emphasis was necessary to ensure rejection of the doctrine barred by section 6 , for the state of the law in

71 \& WIGMORE, EVIDENCE \& 2395 (3d ed. 1940).

72 An excellent presentation of this point of view appears in $\ln r e$ Swenson, 183 Minn. 602, 237 N.W. 589 (1931).

73 Cf., e.g., 8 WIGMORE, EVIDENCE $\$ \$ 2327-28$ (3d ed. 1940) (waiver of attorney-clicat privilege).

${ }^{74}$ See text at note 57 supra. 
regard to crimes and possibly to torts is clearly to the contrary. ${ }^{75}$ It is submitted that the rule barring a privilege when the communication was in furtherance of a future crime should not be applied in a legislative investigation. The court rule denying the privilege in these circumstances requires that it be found from the evidence that the purpose of the communication was wrongful. ${ }^{76}$ Since committee hearings are not limited by the rules of evidence, a "finding" of wrongful purpose too easily could be staged and the vitality of the privileges vitiated. The alternative of requiring the use of traditional rules of evidence to make this finding would be too cumbersome.

Sec. 7. A person who is entitled to a privilege of confidential communication but who is not a ritness at the time the confidential communication is about to be disclosed has the right to claim the privilege personally or through his attorney

(1) at the hearing by a written communication to the chairman of the hearing group prior to the time a witness who might violate the privilege is called to testify,

(2) at the hearing orally whenever a question is asked an answer to which would violate the privilege, or

(3) by mail or other written communication to the chairman of the hearing group if received before a question is answered, which answer could violate the privilege.

Sec. 8. When used in this statute

(1) "committee" means any authorized committee of either House of Congress,

(2) "hearing group" means the committee or subdivision thereof conducting the hearing,

(3) "hearing" means a series of sessions relating to one purpose,

(4) "witness" means anyone testifying before a hearing group, whether or not under oath,

(5) "attorney" means an individual authorized, or reasonably believed by the client to be authorized, to practice law before any federal, state, or territorial court in the United States or under the laws of any foreign country,

(6) "client" means an individual, association, or corporation that directly or through an agent or guardian consults an attorney for the purpose of obtaining legal services or advice from him in his professional capacity,

(7) "doctor" means an individual authorized, or reasonably believed by the patient to be authorized, to practice medicine in any political subdivision in the United States or under the laws of any foreign country, or an individual permitted to practice as a psychologist in the place where the communication took place but only in the course of psychodiagnostics or psychotherapy on behalf of the patient, and

(8) "patient" means an individual who submits himself to diagnosis or treatment by a doctor.

Comment. Subsection (7) imcludes communications between lay psychologists and their patients where diagnosis or treatment of the imdividual patient is the purpose. In such a situation the psychologist is acting essentially as a medical practitioner and the degree of confidence required is manifest. ${ }^{77}$ The scope of this

75 See, e.g., SEC v. Harrison, 80 F. Supp. 226 (D.D.C. 1948) ; 45 CALIF. L. Rev. 75 (1957).

${ }^{76}$ E.g., SEC v. Harrison, supra note 75; Abbott v. Superior Court, 78 Cal. App. 2d 19, 177 P.2d 317 (1947); UNIFORar Rules or Eviderrce rule 26(2) (a) (attorney-client privilege).

77 See Louisell, The Psychologist in Today's Legal World: Part II, 41 MnN. L. REv. 731 (1957); 4 Kan. L. Rev. 597 (1956). 
portion of the doctor-patient privilege may be shown by an illustration: If a psychologist were hired by a business firm to learn einployee reaction to a particular matter, his conversations with employees would not be privileged. But if part of his function were to be available to discuss the personal problems of the einployees with them, as to this inaterial the conversations would be privileged. It is to be noted that since the standards of achievement necessary to practice as a lay psychologist vary so from jurisdiction to jurisdiction, ${ }^{78}$ the protection of the communication has been restricted to the situation where the communication took place where the psychologist is permitted to practice. Further, the psychologist must in fact be permitted to practice; the possibility of successfully asserting falsely that it was "reasonably believed" that the confidant was a psychologist permitted to practice is too clear, much more so than in the case of the medical practitioner.

Donald M. Caken

78 Prior to the close of the present legisiative year, one writer lists only four states having licensure laws for psychologists and six states having certification laws. Louisell, supra note 77 , at 733 nn.5-6. 